\title{
MEMOSISIKAN SASTRA SIBER SEBAGAI LAHAN BARU DALAM PENELITIAN SASTRA MUTAKHIR DI INDONESIA
}

\author{
Uman Rejo \\ (umanrejo@yahoo.com)
}

\begin{abstract}
Cyber literature is literature that covers various genres of work submitted through the electronic media. Ideology contains in the literature cyber is postmodern ideology. Postmodern is difficult to be identified specifically, but the postmodern has common traits that always builds sorting binary opposition. In the current literary research, literary cyberspace is not a study, but rather a "study area". Cyber is the study of literature, not as a "perspective". As study materials, cyber literary phenomenon presents a unique, creative, and challanges a literary researcher. Therefore, the field is classified as current work, should use the latest research model, which is more significant if it is utilized.
\end{abstract}

Keywords:sastra lisan, mantra, folklor

\section{A. PENDAhULUAN}

"Berbagai macam faktor menentukan adanya ciri, fungsi, peran bunyi, gambar, dan aksara yang mengalami pergeseran dari satu wahana ke wahana lain. Kemajuan teknologi yang menunjang kita untuk mengalihwahanakan sesuatu menjadi lebih mudah dan praktis. Kemajuan alat tulis adalah hasil teknologi yang diciptakan manusia untuk memenuhi kebutuhan berkomunikasi dan berekspresi” (Damono, 2012:17). Sastra yang sepanjang sejarahnya selalu erat hubungannya dengan media komunikasi dan informasi, tentunya mendapat tantangan baru yang dihadapi, baik dalam masalah penyampaian atau penyajiannya, maupun dalam masalah kreatifitas para pelakunya. Apabila perjalanan sejarah diamati, perubahan bentuk dan konsepsi artistik karya-karya seni selalu berdampingan dengan pencapaian teknologi pada zamannya.

Dalam dunia sastra sebelum berkembangnya media menulis, sastra dilakukan secara lisan, atau diabadikan pada kulit binatang, batu, dan daun lontar. Setelah kertas ditemukan oleh Tsai'Lun, karya-karya sastra diabadikan pada media tipis ini, sejak dengan tulisan tangan yang indah sampai dengan teknologi cetak yang canggih. Penemuan teknologi cetak oleh Johann Gutenberg telah membuka wilayah baru dokumentasi dan sosialisasi karya sastra secara 
revolusioner. Karya-karya sastra besar yang semula ditulis tangan dan memakan waktu bertahun-tahun untuk menyelesaikan satu eksemplar saja, melalui teknologi cetak dapat diperbanyak sampai ratusan atau ribuan eksemplar. Ketika media komunikasi digital telah merambah kehidupan masyarakat postmodern, dan sastra cetak mulai menampakkan tanda-tanda kejenuhan, sastra pun merembes dan berdenyut di jagat maya (virtual) itu. Dengan demikian, karya sastra dapat disebarluaskan dengan sangat cepat dan mudah.

Pada era digital ini memang membawa kemungkinan-kemungkinan baru dalam perkembangan sastra di Indonesia. Adanya fasilitas blog dan laman di internet, membuka banyak peluang bagi penulis untuk memublikasikan karyakaryanya. Blog dan laman yang tersedia itu ada yang dimiliki secara pribadi, dan adapula yang dimiliki oleh komunitas. Blog yang dimiliki secara pribadi, misalnya blog-nya Joko Pinurbo, Goenawan Mohammad, Maman S. Mahayana, dan sebagainya. Sedangkan blog atau laman yang dimiliki oleh komunitas, misalnya blog dalam laman www.cybersastra.net, www.kolomkita.com, http://sejutapuisi.blogspot.com, www.fordisastra.com, www.mediasastraindonesia.com, www.jendelasastra.com, dan sebagainya. Dengan eksistensi berbagai karya yang sudah diunggah di internet tersebut, baik yang berupa cerpen, puisi, esai, maupun kritik, memunculkan satu genre baru dalam perkembangan sastra mutakhir yang dikenal dengan 'sastra siber'.

Munculnya sastra siber di Indonesia ditanggapi secara beragam. Ada sebagian pihak yang mengapresiasi secara positif dan ada juga yang mengapresiasi secara negatif keeksistensian sastra siber. Pihak yang mengapresiasi secara positif berargumen bahwa melalui media siber, keberadaan dan perkembangan sastra dapat diakses oleh kalangan secara luas, tidak hanya masyarakat Indonesia saja, tetapi juga masyarakat seluruh dunia. Dengan demikian, sastra menjadi milik semua orang karena mereka bisa mencintai dan mengapresiasinya. Sementara itu, pihak yang mengapresiasi mengenai keberadaan sastra siber, yakni berkait dengan kualitas karya yang dihasilkan, karena tidak ada proses seleksi dari pengelola, sehingga semua karya yang bagus dan yang tidak, bisa muncul dalam situs tersebut. 
Herfanda (2004:71), secara kasar menyebut situs yang ada dalam sastra siber ini sebagai “tong sampah". Hal ini dikarenakan oleh keberadaan sastra siber ini hanya menampung dan memuat karya-karya yang pada mulanya tidak termuat di media cetak. Selain itu, ia juga mempertanyakan mengenai keberadaan sastra siber yang hanya dimanfaatkan sebagai media alternatif sosialisasi karya sastra, sebab ia hanya merepresentasikan karya-karya yang pernah termuat di media cetak. Karya-karya sastrawan yang sudah mapan akhirnya disandingkan dengan karya-karya dari para penulis pemula, yang kualitasnya beberapa masih ada yang dipertanyakan, dan mendapat sebutan yang sama sebagai sastra siber. Di sinilah istilah sastra siber menjadi bias.

Dinamika masyarakat yang dipengaruhi oleh modernisasi telah mengubah tatanan kebudayaan dan menumbuhkan jarak antara ideologi-ideologi tertentu. Ideologi tersebut selalu ditanggapi dengan antitesis yang berlebihan, sehingga menimbulkan provokasi terhadap elemen masyarakat tertentu. Tidak hanya itu, sering muncul konflik yang mengatasnamakan suatu ideologi telah menyebabkan kebencian merebak di kalangan masyarakat. Masyarakat merasa tidak masuk pada salah satu lini dan bagian dari teks sastra yang diciptakan oleh sastrawan. Masyarakat merasa bahwa para penulis sastra tidak memperhatikan mereka sebagai objek yang hidup di dalam teks. Padahal, membaca teks sastra adalah mengalaminya, maka teks sastra bukanlah sekadar halusinasi seorang sastrawan semata.

Perlu ditegaskan kembali, bahwa ideologi yang terkandung dalam sastra siberadalah ideologi postmodern. Postmodern memang sulit untuk diidentifikasi secara khusus, tetapi postmodern memiliki ciri-ciri umum yang selalu membangun pemilahan oposisi biner. Selama ini, diketahui bahwa koran merupakan wahana publikasi dalam mendapatkan predikat kesastraan seseorang. Oleh karena itu, dengan munculnya sastra siber, koran bukanlah satu-satunya media legitimasi. Akan tetapi, ada satu hal yang harus digarisbawahi bahwa sastrawan Indonesia masih tetap melestarikan budaya memublikasikan karya sastra di koran. Hal ini lebih sebagai prestise terhadap sastrawan lain. Ada paradigma bahwa diperlukan perjuangan yang luar biasa untuk dapat 
memublikasikan karya sastra di koran nasional, seperti Kompas, Jawa Pos, Suara Merdeka, dan lain sebagainya.

\section{B. PEMBAHASAN}

\section{Ideologi Postmodern}

Sekarang ini manusia tidak lagi hidup dalam era modern, meskipun istilah modern masih terus digunakan dalam berbagai ungkapan dan kepentingan. Manusia sekarang hidup pada era postmodern, yakni suatu era yang telah begitu banyak diulas dan diperbincangkan, tetapi seperti apa gambaran yang tepat mengenai era ini, dan sampai kapan era ini berlangsung, tidak ada yang tahu secara pasti.

Menurut Chambers (1996:194), "budaya postmodern ditandai dengan kabur dan runtuhnya sekat-sekat tradisional antara budaya dan seni, antara budaya tinggi dan budaya rendah, antara dunia bisnis dan dunia seni, serta antara kebudayaan dan bisnis". Sebagai contoh, meningkatnya penampilan dan status budaya pop, yang dipercepat oleh media elektronik telah mengakibatkan kekaburan posisi antara keduanya. Pemilahan antara budaya tinggi dan budaya rendah kini tidak relevan lagi. Budaya tinggi tidak lebih dari suatu subkultur, tidak lebih dari suatu pendapat atau pandangan yang muncul, di tengah-tengah perubahan yang sedang terjadi. Lebih jauh lagi, "goyahnya upaya untuk mempertahankan perbedaan antara budaya tinggi dan budaya rendah, dipadukan dengan pengakuan terhadap audien aktif telah menggagalkan kejelasan kritik komoditas oleh politik 'kiri' dan 'kanan'” (Barker, 2003:157).

Era postmodern yang kita alami sekarang ini merupakan era peradaban pasar. Bahasa dan pola pikir pasar telah mendominasi kehidupan sehari-hari. "Penggunaan konsep untung-rugi, cost benefit analysis, return of investment, portofolio, sudah menjadi bagian dari hampir semua kegiatan dalam berbagai aspek kehidupan, terutama tercermin dari iklan dan ekspansi logika pasar" (Imam, 2003:300). Peradaban pasar dikhawatirkan menjadi pemicu terjadinya proses homogenisasi budaya. Produk-produk budaya global yang digerakkan pasar terus mendesak, dan bahkan mulai menenggelamkan berbagai produk budaya lokal. 
Dalam era teknologi informasi ini, proses homogenisasi budaya sedang berlangsung dengan kekuatan penuh.

Peradaban pasar tidak hanya mengubah gaya hidup lokal menjadi global, tetapi juga mewarnai perkembangan, ketahanan, dan nasib berbagai produk kebudayaan dan peradaban yang berlabel lokal. Ranah pemakaian bahasa, apresiasi sastra, dan penggunaan produk-produk kebudayaan lokal kini makin menyempit dan termarginalisasikan. Bahasa, sastra, dan budaya tidak mendapat respon positif dan dibina pasar, karena secara ekonomi ketiganya tidak bisa menciptakan profit atau keuntungan yang berarti. Oleh para pemerhati budaya, gejala kebudayaan tersebut kemudian mencoba dihambat dengan gerakan penangkal yang disebut dengan gerakan heterogenisasi budaya (cultural heterogenization).

"Tentu saja kedatangan postmodern tidak berarti akhir dari kapitalisme" (McGuigan, 2006:2-3). Era ini dapat dikatakan sebagai pergeseran dalam pengetahuan dan kebudayaan. Jika ada transisi yang terjadi dari bentuk peradaban yang satu kepada bentuk peradaban yang lain, dari modernitas ke postmodernitas, maka hal tersebut disebabkan lebih oleh pemaknaan terhadap perkembangan pengetahuan dan kebudayaan melalui cara mengetahui, menggambarkan, dan mengenali berbagai gejala yang berbeda, daripada oleh faktor-faktor material konvensional yang biasa dibahas dalam Ilmu Ekonomi dan pemanfaatan alam. Deklarasi postmodern, yang utama dan terutama, berkaitan dengan subjektivitas dan ide, bagaimana kita berpikir dan memberi arti: bukan semata-mata suatu klaim tentang realitas material. Deklarasi ini didukung oleh asumsi bahwa tidak ada realitas material yang dapat dilihat secara objektif, bagaimanapun juga, pastinya bukan sesuatu yang terletak di luar pikiran dan pengertian. Oleh karena itu, postmodernisme dapat dilihat sebagai idealisme filosofis dan reduksionisme kultural, atau sebagai pembalikkan dari reduksionisme ekonomi. Karena alasan ini, postmodernisme secara luas diperebutkan oleh mereka yang ingin berargumentasi, misalnya, bahwa ada interaksi yang kompleks antara ekonomi dan kebudayaan, dan bahwa sosialitas dapat direduksi menjadi bukan roti dan mentega atau hiburan dan permainan. 
Menurut Appadurai (dalam Uncapher, 1995:2), ada lima aliran besar yang mendorong laju peradaban pasar yang mengusung proses homogenisasi budaya dan mengancam eksistensi serta ketahanan bahasa, sastra, dan kebudayaan suatu bangsa atau masyarakat. Pertama, ethnoscapes 'aliran manusia', berkait dengan migrasi berbagai kelompok etnis dari satu negara ke negara lain. Mereka bukan hanya menularkan informasi baru tetapi juga kebudayaan dan cara hidup baru, secara langsung dan tidak langsung mereka melakukan penetrasi budaya. Kedua, mediascapes 'aliran media', berkait dengan penyebaran informasi melalui berbagai media seperti surat kabar, majalah, stasiun televisi, film, dan internet yang memiliki begitu banyak peminat dan mencuatkan citra-citra baru. Ketiga, finanscapes 'aliran modal'. Keempat, technoscapes 'teknologi canggih'. Kelima, ideoscapes 'aliran ideologi'. Antara finanscapes, technoscapes, dan ideoscapes, baik yang dapat diterima atau berlawanan, baik yang moderat maupun yang radikal, mengalir dengan deras ke berbagai negara dan 'menggenangi' kehidupan manusia.

"Postmodern adalah sebuah gejala yang membingungkan. Pikiran manusia terseret oleh wacana yang terkait dengan resistensi, pemindahan, dan perubahan gagasan tentang kebudayaan yang disimpulkan layaknya fenomena limbah, sesuatu yang sia-sia dan merupakan ekses" (Featherstone, 2007:21-22). Produkproduk yang dikeluarkan tidak dikaitkan dengan kebutuhan tetapi dengan akses. Akibatnya, tujuan produksi menjadi destruktif, dan kunci masalahnya berubah dari menyejahterakan menjadi sumber produk. Kelebihan energi diterjemahkan menjadi kelebihan produk dan barang, suatu proses pertumbuhan yang mencapai titik batasnya dalam entropi dan anomi. Untuk mengendalikan pertumbuhan secara efektif dan mengelola surplus, satu-satunya solusi adalah meminggirkan ekses yang mencuat dalam bentuk permainan, agama, seni, perang, dan kematian. Pertumbuhan ekonomi dilakukan melalui iming-iming berupa hadiah, berbagai turnamen, karnaval, dan konsumsi yang mencolok mata. Kapitalisme memproduksi citra dan situs konsumsi untuk membangun kenikmatan suasana secara berlebihan. Citra dan situs tersebut senyatanya makin mengaburkan batas-batas antara seni dan kehidupan sehari-hari. 
"Pada era postmodern manusia kehilangan banyak hal karena terdesak oleh perubahan. Hilangnya pemahaman sejarah sebagai sebuah "narasi" yang linier dan berkesinambungan, dengan rangkaian peristiwa yang jelas, merupakan indikasi dari argumen bahwa dalam dunia postmodern metanarasi sedang ditumbangkan” (Strinati, 2009:341-342). Metanarasi yang dimaksud termasuk agama, ilmu pengetahuan, seni, modernisme, dan Marxisme, yang senyatanya telah memberikan pernyataan yang absolut, universal, dan mencakup semua hal yang berkenaan dengan pengetahuan dan kebenaran. Teori postmodernis sangat skeptis terhadap metanarasi-metanarasi tersebut, dan mengatakan bahwa semua itu terbuka untuk dikritik atau dipertanyakan kembali. Dalam dunia postmodern, metanarasi menjadi terpecah-berai, validitas dan legitimasinya nyaris runtuh, manusia semakin sulit untuk menyusun dan menginterpretasi kehidupannya melalui rujukan atau tuntutan metanarsi macam apa pun. Oleh karena itu, sebagai metanarasi, agama dan filsafat terancam kehilangan makna dan fungsinya dalam masyarakat postmodern.

Pada era postmodern, pemaknaan tentang pengetahuan (knowledge) juga telah berubah. Dalam pandangan Lyotard (1993:4-5), pengetahuan kini telah berhenti menjadi tujuan dalam dirinya, atau kehilangan nilai gunanya (its "usevalue"). Prinsip lama yang mengatakan bahwa kepiawaian akan pengetahuan merupakan sesuatu yang tidak dapat dipisahkan dari latihan akal, atau bahkan individu, telah menjadi usang dan akan tetap usang. Hubungan antara pemasok dan pengguna pengetahuan dengan pengetahuan yang mereka pasok dan gunakan sekarang ini cenderung, dan akan terus cenderung mengambil bentuk yang sudah diambil oleh hubungan antara produsen dan konsumen, yakni dalam bentuk nilai jual. Pengetahuan diproduksi atau akan diproduksi untuk dijual, dan pengetahuan tersebut dikonsumsi dengan cara dikemas dalam bentuk produksi baru.

Postmodernisme telah mengambil perhatian yang mendalam terhadap fenomena bahasa dan kebudayaan, tepatnya untuk menyatakan bahwa pemahaman terhadap diri seseorang bukan hanya dapat dilakukan melalui hal-hal atau gejalagejala yang bersifat universal, tetapi juga melalui hal-hal khusus yang terdapat pada suatu kebudayaan tertentu. Gejala kebudayaan seperti ini sangat memengaruhi proses kreatif seorang sastrawan yang senyatanya berperan sebagai 
pencatat kehidupan dan perjalanan peradaban. Postmodernisme ekstrem menolak adanya unsur-unsur universal dalam dunia kebudayaan, terutama dalam alam isinya, sedangkan mereka yang moderat berpendapat bahwa apa saja yang dipikirkan, dicita-citakan, dan dialami telah disampaikan kepada manusia melalui produk-produk kebudayaan.

"Manusia postmodern adalah manusia yang mengidap berbagai penyakit kecanduan (addicated) akibat kemajuan ilmu pengetahuan dan teknologi. Selain kecanduan halusionogen, manusia postmodern pada abad ke-21 ini juga kecanduan obat-obatan elektronik (electronic drugs), seperti media televisi, video, videos game, telepon seluler, komputer, dan internet. Setiap medium tersebut menyimpan dan menyebarkan informasi secara global dengan tempo yang tinggi dan volume yang padat. Masyarakat dunia kini bermukim di sebelah plenum, yaitu sebuah ruang yang dipenuhi informasi sehingga tidak ada satu sudut pun yang tidak tersentuh oleh informasi. Di dalam ruang padat informasi, tetapi juga terseret dan terjebak oleh arus informasi. Gejala seperti itu tampak jelas pada fenomena cyberspace" (Piliang, 1998:350-352). Sastrawan sebagai warga bumi yang juga bermukim di plenum yang sama harus menghadapi gejala peradaban yang sama.

Untuk memperoleh informasi, seseorang kini tidak harus menjelajah ruang nyata, tetapi cukup duduk santai dan menikmati berbagai informasi cyberspace. Dunia manusia kini bukan hanya dipenuhi dengan arus informasi, baik yang mengalir melalui dunia nyata maupun dunia maya, akan tetapi juga dipenuhi oleh dunia objek. Objek-objek tersebut merupakan relasi-relasi sosio-kultural yang dibangun secara global, yang peran dan fungsinya sejajar dengan manusia. Abad ke-21 merupakan abad hiperkonsumerisme, yakni ketika konsumsi menjadi pusat dari kehidupan sosial, ketika benda menguasai manusia. Di dalam masyarakat hiperkonsumer manusia dikelilingi oleh benda-benda. Manusia tidak lagi sekadar berbicara dengan benda-benda sebagai media, tetapi berdialog dengan bendabenda bersangkutan. Benda-benda tersebut menjadi kenikmatan, kesenangan, kenyamanan, kegairahan, dan simbol status. Berbagai bentuk ritual baru, seperti opening seremony, cllubbing, social gathering, fans club, antifans club, facebook, 
fashion show, twitter memperlihatkan betapa pentingnya peran dunia benda dalam kehidupan manusia postmodern.

Pada era postmodernisme ini, dunia sastra juga mengalami perubahan besar. Jika kata "post" dalam istilah 'postmodernisme' semata-mata mengacu pada manifestasi seni modern mutakhir sebagai praktik elit, suatu laboratorium representasi, hal itu akan menjadi tidak signifikan. Fredric Jameson pernah mengatakan bahwa "postmodernisme merupakan logika kultural yang dilahirkan oleh kapitalisme". Kebudayaan postmodernisme kalau mengacu pada pendapat Fredric Jameson tersebut, dapat difahami sebagai kebudayaan pada umumnya, termasuk kebudayaan pop-massa kontemporer, teks-teks media, dan pengalaman sehari-hari, difahami pada model bidang kekuatan atau struktur perasaan. Ia merupakan sarana yang lebih memuaskan untuk memahami apa yang sedang terjadi secara budaya sekarang ini daripada konsepsi postmodern yang elitis dan terbatas yang tidak dapat dibedakan dari memori dan jejak peninggalan modernisme garda depan.

Berbagai pandangan tentang kebudayaan postmodern diberikan dalam kesusastraan, seperti, antara lain lima ciri menentukan yang dikemukakan oleh Dominic Strinati (dalam McGuigan, 2006:6), yakni: (1) kaburnya perbedaan antara kebudayaan dan masyarakat; (2) terjadi penekanan pada gaya dengan mengorbankan substansi dan isi; (3) robohnya perbedaan antara kebudayaan tinggi (seni) dan kebudayaan populer; (4) munculnya kekacauan terhadap ruang dan waktu; dan (5) merosotnya metanarasi. Semua gejala yang dikemukakan ini sangat memengaruhi dunia kesusastraan yang meliputi penciptaan, apresiasi, penilaian, pendekatan, dan bentuk sastra. Nyoman Kutha Ratna (2004:6) menambahkan bahwa modernisme dan postmodernisme dalam sastra berkaitan dengan ciri-ciri karya sastra itu sendiri, bukan terletak pada teorinya.

\section{Peluang Sastra Siber}

Sastra siber dapat didefinisikan sastra yang mencakup berbagai genre karya yang disampaikan melalui media elektronik. Sastra siber telah mulai ada semenjak adanya wadah IT, yang memungkinkan pengguna-pengguna komputer untuk memanfaatkan media internet secara bebas dan tidak terjaga. Dalam waktu yang sama, meskipun ia memiliki kesamaan dari segi penyampaian wadah isi 
dengan media cetak, ada banyak kelebihan dan kelemahan yang ada pada sastra siber melalui media elektronik. Kelebihan-kelebihan sastra siber, yakni semakin luasnya media sastra dan menambahkan berbagai genre sastra dalam penulisannya, berbeda dengan sastra dengan media cetak yang perlu menggunakan pembayaran atau aturan ribet dalam pemublikasikannya, sastra siber sangat simpel dan gratis.

Selain itu, meskipun sastra melalui media cetak dapat diperoleh seseorang secara lahiriah, namun, ia tidak dapat memastikan bahwasanya sastra media cetak seperti buku, majalah atau surat kabar itu akan bisa tahan lama. Dengan demikian, berbeda dengan sastra siber, pengguna dapat menyimpan setiap karya sastra yang telah dihasilkan melalui dunia maya. Tindakan ini adalah bukan tindakan yang tidak mustahil dengan adanya berbagai struktur dan bentuk situs yang tersedia di dalam internet.

Jadi, secara keseluruhan adanya sastra siber yang bersifat inovatif dan kreatif, akan melahirkan berbagai macam genre sastra, yaitu sastra jurnal, sastra kritik, sastra visual, sastra bisnis, sastra komunikasi, serta sastra informasi. Dengan lahirnya sastra siber, luas inovasi tidak akan terbatas sebaliknya akan terus berkembang dengan pengenalan daya cipta baru dalam upaya memanusiakan internet dan ruang alternatif bagi penerbitan, pendokumentasian, ekspresi zat hasrat dan pandangan, serta interaksi visual. Maka sastra siber ini sangat sejalan dengan perkembangan sastra visual yang sangat relevan dengan kebutuhan masa kini.

\section{Metode Penelitian Sastra Siber}

Dalam bukunya Membaca dan Menilai Sastra (1983), Teeuw mengatakan pemahaman terhadap karya sastra harus memperhatikan tiga kode, yakni kode sastra, kode budaya, dan kode bahasa. Demikian halnya dengan sastra siber, tiga kode tersebut ternyata juga terdapat dalam sastra siber. Kode sastra berhubungan dengan aspek-aspek "citraan" sastra siber yang amat sulit. Jika dilihat dalam karya-karya puisi, sebagian besar menggunakan citraan kata-kata sederhana, tetapi bermakna luas. Pada dataran semacam ini, kadang-kadang "bungkus" citra merupakan makna yang luar biasa. Oleh karena itu, penelitian sastra siber akan 
bertaruh memahami citraan yang sering abstrak. Citraan tersebut sering bergumul dengan realitas dunia yang serba pseudo-real (kenyataan semu) atau hiperealitas.

Kode budaya sastra siber, akan berhubungan dengan aspek-aspek khusus yang disebut teknologi canggih, yakni sebuah budaya industri, yang selalu meneguk keuntungan tertentu. Budaya industri selalu menyuguhkan sebuah komoditas, sehingga peran masyarakat kapitalis akan menentukan makna sastra siber itu sendiri. Kemungkinan besar, penulis sastra siber masih berat meninggalkan kapitalisme, sehingga sastra siber independen masih dalam bayangan. Kode bahasa, jelas sekali menunjukkan bahasa gaul yang spektakuler. Bahasa yang singkat padat, penuh humor, dan memuat makna yang dalam akan mengundang pemaknaan tersendiri. Peneliti akan dihadapkan pada penampilan bahasa khas, terutama ketika kode ini berbaur dengan seni instalasi.

Dalam kaitan ini, Suwardi Endraswara mengatakan bahwa peneliti sastra siber dapat memfokuskan pada aspek-aspek permasalahan berikut. Pertama, manfaat sastra siber dari waktu ke waktu. Kedua, perkembangan sastra siber sejak kemunculannya sampai kini. Ketiga, seberapa jauh mutu karya-karya dalam sastra siber. Keempat, seberapa jauh tanggapan pembaca sastra siber. Kelima, diperlukan studi sastra bandingan antara sastra siber dengan sastra koran. Kehadiran sastra siber dalam ranah sastra mutakhir di Indonesia telah menampilkan sebuah sistem sastra yang unik. Setidaknya, dengan adanya sastra siber para penulis telah membangun sebuah ekologi sastra terbaru. Selain itu, sastra siber juga telah merobek sekat-sekat negara dalam bersastra.

Adapun metode penelitian sastra siber dapat dikategorikan ke dalam tiga metode utama, yakni metode penelitian tekstual, metode penelitian produksikonsumsi, dan metode penelitian pembaca. Penelitian tekstual sastra siber dapat memanfaatkan teori formalisme, new criticism, strukturalisme, semiotika, naratologi, dekonstruksi, dan kajian budaya (cultural studies). Penelitian produksi-konsumsi sastra siber dapat memanfaatkan teori sosiologi, teori ekonomi, dan psikologi sastra. Penelitian pembaca sastra siber dapat memanfaatkan teori estetika resepsi dan respon pembaca. Di samping metodemetode tersebut, penelitian sastra siber juga dapat memanfaatkan teori-teori posstrukturalisme, postmodernisme, dan teori-teori kritis yang lain. 
Pembacaan terhadap teks sastra dapat dipilah ke dalam dua kategori, yakni membaca sebagai ajaran (reading for understanding) dan membaca sebagai hiburan (reading for enjoyment). Kategori pertama digunakan dalam membaca teks sastra yang mempunyai bobot sastra yang tinggi, sedangkan kategori kedua digunakan dalam membaca teks sastra yang mempunyai bobot sastra yang rendah, seperti sastra siber. Dengan menggunakan cara berpikir hirarkis, membaca dengan kategori pertama itu interpretif, kritis, dan serius; sedangkan membaca dengan kategori kedua itu eskapis, sepintas-lalu, dan main-main. Meskipun demikian, dengan menggunakan cara berpikir heterarkis, kategorisasi tersebut dapat disubstitusikan. Membaca teks sastra siber dapat dilakukan secara interpretif, kritis, dan serius, misalnya dalam konteks pembacaan akademik.

\section{Peran Teori Sastra}

Perbedaan pendapat mengenai ontologi dalam teori sastra tidak akan pernah berakhir. Secara umum, perbedaan pendapat tersebut menyangkut dua hal yakni bagaimana bentuk hubungan yang seharusnya terjadi antara objek penelitian dengan teori itu sendiri sebagai alat dan seberapa jauh teori tersebut relevan terhadap objek penelitian sebab kenyataannya sebagian besar teori-teori yang dimaksudkan berasal dari Barat. Untuk memecahkan permasalahan pertama disepakati bahwa yang terpenting adalah pemahaman terhadap objek, sehingga hasil-hasil penelitian dapat dimanfaatkan oleh masyarakat secara luas. Pada umumnya permasalahan yang kedualah yang selalu menimbulkan perdebatan dengan alasan bahwa teori dan objek lahir melalui latar belakang dan tradisi budaya yang berbeda.

Terlepas dengan perbedaan latar belakang sosial antara teori dan objek di depan, kenyataannya menunjukkan bahwa sudah hampir setengah abad, sejak tahun 1960-an hingga sekarang, sejak lahirnya teori strukturalisme, teori-teori Barat sudah dimanfaatkan secara intens dalam penelitian sastra. Masalah yang perlu dipecahkan bukan masalah teori Barat atau non-Barat, tetapi bagaimana teori-teori tersebut dioperasikan, dimodifikasi, sehingga tidak mengorbankan hakikat objek.

Hal lain yang perlu dipertimbangkan, dalam rangka globalisasi, pada dasarnya tidak perlu diperdebatkan apakah suatu teori merupakan teori asing atau 
pribumi. Hal yang perlu disadari adalah kenyataan bahwa sampai saat ini kita belum mampu untuk menghasilkan teori seperti yang dihasilkan oleh para sarjana Barat. Dalam rangka globalisasi, khususnya dengan hadirnya paradigma postmodern, baik khasanah sastra Indonesia maupun keseluruhan teori dan metode yang digunakan sebagai alat untuk menganalisis dianggap sebagai warga sastra dunia, dan dengan sendirinya memiliki kedudukan yang sejajar. Teori tidak mesti digunakan secara keseluruhan, teori dapat dimodifikasi. Meskipun demikian, dalam rangka memajukan khazanah sastra Indonesia, pada saat inilah, teori pribumi, yakni teori yang digali melalui kompetensi bangsa, mutlak perlu dikembangkan.

\section{PENUTUP}

Sastra siber merupakan sastra yang mencakup berbagai genre karya yang disampaikan melalui media elektronik. Ideologi yang terkandung dalam sastra siberadalah ideologi postmodern. Postmodern memang sulit untuk diidentifikasi secara khusus, tetapi postmodern memiliki ciri-ciri umum yang selalu membangun pemilahan oposisi biner. Dalam penelitian sastra mutakhir, sastra siber bukanlah sebuah kajian, melainkan sebuah "wilayah kajian". Sastra siber menjadi bahan kajian, bukan sebagai "cara pandang”. Sebagai bahan kajian, sastra siber menyuguhkan fenomena yang unik, kreatif, dan menantang seorang peneliti sastra. Kehadiran sastra siber dalam ranah sastra mutakhir di Indonesia telah menampilkan sebuah sistem sastra yang unik. Setidaknya, dengan adanya sastra siber para penulis telah membangun sebuah ekologi sastra terbaru. Oleh karena wilayah garap ini tergolong mutakhir, seyogianya pemanfaatan model penelitian terbaru pun lebih signifikan jika dimanfaatkan.

\section{DAFTAR PUSTAKA}

Barker, Chris. 2003. Cultural Studies: Theory and Practice. London: Sage Publication.

-----. 2004. The Sage Dictionary of Cultural Studies. London: Sage Publications.

Budianta, Melani. 2002. "Teori Sastra Sesudah Strukturalisme: dari Studi Teks ke Studi Wacana Budaya". Makalah Pelatihan Teori dan Kritik Sastra di PPPG Bahasa Universitas Indonesia pada 27-30 Mei 2002. 
Chambers, I. 1996. Popular Culture: The Metropolitan Experince. London: Methuen.

Damono, Sapardi Djoko. 1991. "Kenyataan, Dugaan, dan Harapan: Tentang Perkembangan Sastra Kita Akhir-akhir ini” dalam Seni dalam Masyarakat Indonesia: Bunga Rampai. Edi Sedyawati dan Sapardi Djoko Damono (Editor). Jakarta: Gramedia Pustaka Utama.

-----. 2009. Kebudayaan Populer (di Sekitar) Kita. Depok: Editum.

-----. 2012. Alih Wahana. Ciputat: Editum.

Darma, Budi. 2007. "Sastra Mutakhir Kita" dalam Bahasa, Sastra, dan Budi Darma. Djoko Pitono (Editor). Surabaya: JP Books.

Featherstone, Mike. 2007. Consumer Culture and Postmodern. London: Sage Publications.

Herfanda, Ahmadun Yosi. 2004. "Puisi Cyber, Genre atau Tong Sampah" dalam Cyber Grafitti: Polemik Sastra Cyberpunk, Kumpulan Esai. Saut Situmorang (Editor). Yogyakarta: Jendela.

Imam, Robert H. 2003. Neoliberalisme. Yogyakarta: Cindelaras Pustaka Rakyat Cerdas.

Lyotard, Jean Francois. 1993. The Postmodern Condition: A Report on Knowledge. Oxford: Manchester University Press.

McGuigan, Jim. 2006. Modernity and Postmodern Culture. England: Open University Press.

Ong, J. Walter. 2002. Orality and Literacy: The Technologizing of the Word. London and New York: Routledge Taylor and Francis Group.

Piliang, Yasraf Amir. 1998. SebuahDunia Yang Dilipat: Realitas Kebudayaan Menjelang Milenium Ketiga dan Matinya Postmodernisme. Bandung: Mizan.

Ratna, Nyoman Kutha. 2004. "Relevansi Teori-Teori Postrukturalisme dalam Memahami Karya Sastra, Aspek-Aspek Kebudayaan Kontemporer pada Umumnya". Pidato Pengukuhan Jabatan Guru Besar dalam Bidang Ilmu Sastra di Fakultas Sastra Universitas Udayana Denpasar, 1 Mei 2004.

Strinati, Dominic. 2009. Popular Culture. Yogyakarta: Ar-Ruzz Media.

Teeuw, A. 1983. Membaca dan Menilai Sastra. Jakarta: PT Gramedia Pustaka Utama.

Uncapher, Willard. 1995. "Placing the Mediascape in the Transnational Cultural Flow: Learning to Theorize an Emerging Global Grassroots Infrastructure". (Online). (http://www.well.com/-willard/global3b.html diakses pada tanggal 25 April 2013). 